\title{
When Empowerment Disempowers: A case study of Ghana's Community- Based Rural Development Projects
}

\author{
Kwadwo Adusei-Asante and Peter Hancock \\ School of Psychology and Social Science, \\ Edith Cowan University, \\ Joondalup, Australia \\ Email: \\ DOI:http://dx.doi.org/10.4314/gjds.vgi2.3
}

\begin{abstract}
This paper argues that the term 'empowerment' is too complex a concept to be simply 'inserted' into development project designs without prior and precise conceptualization. Drawing on qualitative research conducted in 2010/2011 and using Ghana's Community-Based Rural Development Projects (CBRDP) as a case study, the paper outlines power struggles that occurred between Traditional Chiefs and Local Government Officials over the right to manage the projects. The analysis shows that the mal-application of 'empowerment' in the CBRDP's design impacted negatively on the projects. As the project's officials did not envisage the feuds there was no strategy in place to monitor and manage unintended outcomes. The paper provides a theoretical and empirical basis for policy-makers and program officials to consider more carefully the politico-cultural contexts of 'development' beneficiaries rather than focusing on positivistic and normative terms, such as empowerment, which seems to characterize many development projects at the global level.
\end{abstract}

KEYWORDS: Empowerment, Local Government, Chieftaincy, Development policy, Community-Driven Development.

\section{Introduction}

This paper argues that the concept of 'empowerment' is too complex to be 'cut and pasted' into development aid project designs. 'Empowerment' seems to be 'marketed' as being inherently 'good' and a value that the powerless should pursue, or that they should be aided in their obvious quest to become empowered. However, the paper considers the 
concept of 'empowerment' as complicated, providing theoretical and empirical arguments for how its malapplication in development programs designs can impact negatively on outcomes. The findings show the need for development practitioners to go beyond conceptualizing the term normatively to appreciating its complication and contextualized application. This is very critical for settings where politico-cultural institutions are very influential.

The paper is based on the study of Ghana's Community-Based Rural Development Projects (CBRDP); it shows how the project's quest to empowering local government officials unconsciously resulted in the disempowerment of Traditional Chiefs. The CBRDP aimed to contribute to the overall 'empowerment' of the rural population, while simultaneously strengthening the country's decentralization system (CBRDP Implementation Manual, 2006). The CBRDP served as one of the principal vehicles for the implementation of Ghana's Poverty Reduction Strategy (GPRS) to bridge the gap of uneven distribution across socio-economic groups and geographical locations (CBRDP Implementation Manual, 2006). The project also aimed to strengthen Ghana's local government substructures (Area Councils and Unit Committees) as planners and implementers of development initiatives at the local level. Before the implementation of the CBRDP the local government substructures were virtually in a state of inertia; some scholars questioned their relevance and existence (See Ahwoi 2005, 2010; Antwi-Boasiako 2010). Thus, the CBRDP was the inaugural nation-wide program specifically designed to test the project implementation capabilities of Area Councils (CBRDP

Implementation Manual, 2006; Yaron, 2008). The World Bank's International Development Association and the Agence Francaise Development provided loan facilities for the project. The CBRDP was implemented under the supervision of the Ministry of Local Government and Rural Development (MLGRD) and the Regional Coordinating Units (RICUs) in conjunction with an independent CBRDP secretariat. The project was piloted between 2005 and 2011 in all ten regions, all hundred and thirty-eight Districts/ Municipalities, and one hundred and forty five Area Councils² (CBRDP Implementation Manual, 2006; Binswanger, de Regt \& Spector, 2010).

Regarded as the custodians of the lands in the country, the Chieftaincy institution is recognized and enshrined in Article 246 of Ghana's Constitution, which restricts the state from interfering in its affairs. Owing to its importance, a ministry has been established to oversee Chieftaincy affairs in the country. Aside from being constitutionally recognized, $30 \%$ of the seats of District Assemblies are also reserved for Traditional Chiefs, while the Assembly also pays them 22.5\% of the revenue from Stool Lands (Donkor, 2005; Ahwoi, 2010). In a survey conducted in Greater Accra in 2005, over 50\% of the 1005 respondents stated that Traditional Chiefs were more powerful than Members of Parliament (Knierzinger, 2011). The institution has since 1980 realized some form of modernization. Unlike the pre-1980 period, Ghanaian Traditional Chiefs are now acquiring formal

2 Currently, the projects are completed and handed over to the local communities to maintain, but not without challenges 
education, with some setting up foundations for improving education, healthcare and environmental sensitization in their respective traditional areas (Knierzinger, 2011). These initiatives and modernization of the institution have in a sense augmented the influence of Traditional Chiefs as brokers of social capital, an important ingredient in local development (see Putnam 2002;Tesoriero 2010).

Apart from Ghana (see Adusei-Asante, 2012), there is evidence that Traditional Chiefs have been influential in the implementation of various CDD programs in West African countries such as Senegal and Benin (Arcand \& Bassole, 2007; Binswanger et al. 2010). By implication, and as confirmed by some scholars (Mansuri \& Rao, 2004; Abotchie, 2006; Ahwoi, 2010, Knierzinger, 2011), Traditional Chiefs wield the power to determine the fate of development projects in African contexts. Their authority notwithstanding, the designers of Ghana's CBRDP, as will be discussed below, seemed to have sidelined Traditional Chiefs. The oversight, which led to intense feuds, also impacted negatively on the maintenance and outcomes of the CBRDP at the time of the fieldwork. This outcome, the paper argues, was invariably attributable to the mal-application of the concept of empowerment in the design of the CBRDP.

\section{Methods}

The paper draws on the review and analysis of relevant academic literature and qualitative data during a seven months fieldwork (2010-2011) designed to unearth the manner in which Ghana's CBRDP was impacted by the application of contested theories and complex concepts. The qualitative data was generated from participant-observation and interviews with Traditional Chiefs, Local Government Organizations, CBRDP Managers, key informants and residents of the case study localities. Participants were purposively sampled and had to be living in the study localities. They also had to possess intimate knowledge of the CBRDP implementation processes. The interview questions, which were semi-structured elicited information on the 1) Processes leading to the selection and implementation and the state of the CBRDPs; 2) Role of Traditional Chiefs in the selection and implementation of the CBRDPs; and 3) Relationship between Traditional Chiefs and LGOs. The data was analyzed manually. The themes that emerged are presented this paper. The analysis suggests that in their pursuit to strengthen Ghana's decentralization process through the CBRDP, designers of the project ${ }^{3}$ appear to have focused only on the local government sub-structures, while overlooking the country's influential politico-cultural heritage.

\section{Empowerment: Background and Conceptual Issues}

Although 'empowerment' discourse has its roots in Frierean philosophy (Cleaver, 2001), since 2000, the concept has become increasingly popular in development studies with a

3 Ghana's Ministry of Local Government and World Bank Advisors. 
significant body of literature, typically divided into distinct schools of thought, discussing it in various ways (World Bank, 2000a; 2002; Clifford, 2001; Mosse, 2001; Narayan, 2002; Cornish, 2006; Binswanger et al. 2010; Hancock et al. 2011; Maseno \& Kilonzo, 2011). The World Bank (2002: 11) defines 'empowerment' as, "the expansion of freedom of choice and action. It means increasing one's authority and control over the resources and decisions that affect one's life." The World Bank argues that there is no single model of 'empowerment', and has put forward four elements which characterize the concept: 1) Access to information; 2) Inclusion and participation; 3) Accountability; and 4) Local organizational capacity.

The World Bank's definition appears to value the term for its normativity and complexity. In the normative sense, they regard empowerment as being inherently 'good'; when targeted populations are 'empowered', powerless and vulnerable people may be able to participate in their 'communities', reduce their poverty levels, and have a sense of confidence and independence (see also Cornish, 2006; Anyidoho \& Manuh, 2010). The World Bank argues further that the common elements underlying poverty is the exclusion, voicelessness and powerlessness of the poor; and that, faced with unequal power relations, the poor lack the influence to negotiate better terms for themselves (World Bank, 2000a; 2002; 2003b). In this regard, the World Bank and other scholars (See Narayan, 1995, 2002; Botchway, 2001; Cornish, 2006; Anyidoho \& Manuh, 2010) have argued for the need to address unequal power relations in order to expand the opportunities and choices of the poor. To achieve this, proponents of the concept of empowerment (see Narayan, 1995, 2002, Zimmermann, 1995; Dollar \& Burnside, 2000; Nussbaum, 2000; Lavarack \& Wallenstein, 2001; Binswanger et al., 2010) have argued for the strengthening of local institutions to be the instrument for empowering the powerless at the grassroots level; hence the World Banks' support of Ghana's CBRDP. Beyond Ghana, the notion that the empowerment is positive has also influenced the objective of many development initiatives of the UNDP and the World Bank. For example, United Nation's MDG 3 aims to "promote gender equality and empower women" (Sachs 2005; MDG Report, 2011). Currently, operating through its 'Empowerment' Team, the World Bank is one of the chief campaigners of the concept and employs it in a range of sectors ${ }^{4}$.

The World Bank (2002) concedes that there is no single model of 'empowerment', an apparent appreciation of the complexity of the term. Three conceptual and theoretical issues, which characterize the complexity of the term, may be considered. First, although the term is inherently generic, its contemporary use and application appears to have been made 'gender-specific'. Since 2001, there seems to have been a consistent effort by the World Bank to 'engender empowerment'. A World Bank policy document, Engendering Development through Gender Equality in Rights, Resources, and Voice (World Bank, 2001), provides insights into tools for integrating gender into development work.

4 http://go.worldbank.org/EEU9PYCWUo; retrieved February 25, 2012. According to Alsop et al. (2006) in 2005 , over 1,800 projects in the World Bank's lending portfolio related to 'empowerment'. 
Furthermore, between 2006 and 2010, more than $\$ 65$ billion, representing $37 \%$ of all the World Bank's lending and grants, were allocated to gender-informed operations. ${ }^{5}$ The notion of engendering 'empowerment' also seems to underlie MDG 3, the 2012 World Development Report and the ideals of organizations such as United Nations Entity for Gender Equality and the Empowerment of Women ${ }^{6}$.

While 'empowerment' is applicable to either gender, due to gender inequality and the prevalence of patriarchy globally, a focus on women is justified and should continue until equality is achieved (Apusigah, 2004a; 2004b; Cornwall \& Edwards, 2010; Hancock, Middleton, Moore \& Edirisinghe, 2011). However, negative outcomes result when the term is used vaguely and is not theoretically explicit vis-a-vis gender specific outcomes, and 'forced' into development projects, as Adusei-Asante (2013) argues in the case with Ghana's CBRDP.

Second, scholars disagree on whether 'empowerment' refers to a process or an outcome or both. According to Mosedale (2003) 'empowerment' is an ongoing process rather than a product, and that there is no final goal. Put in absolute terms, Mosedale argues that one does not arrive at a stage of being empowered. Others argue that 'empowerment' is both a process and an outcome. As a process, it involves building the capacities, skills and competencies of either an individual or a group of people over a period of time, from a lower to a higher state of 'empowerment'. As an outcome, 'empowerment' becomes an end in itself, where an individual or group enjoys a state of 'empowerment' (Arnstein, 1971; Lavarack \& Wallenstein, 2001; Cornish, 2006; Binswanger et al. 2010; Tesoriero, 20107).

The lack of consensus on whether 'empowerment' is a process or an outcome or both has critical implications for its measurement. Measuring 'empowerment' according to Yaron (2008) is an important indicator of a country's performance and opportunities available to an individual. At the country level, he argues, 'empowerment' indicators contribute to the process of strengthening governance and reducing corruption. Yaron argues further that empowerment aims at developing the capabilities of the individual not just as beneficiaries, but also as agents capable of effecting institutional change. What then are the indicators for measuring empowerment outcomes?

Many independent scholars have suggested various models that provide indicators for measuring 'empowerment' (Mosedale, 2003; Alsop, Bertelsen \& Holland, 2006; Yaron, 2008). As individuals and groups may seek different forms of 'empowerment', the models above appear to be contextualized and cannot be generalized (Zimmermann, 1995; Lavarack \& Wallenstein, 2001; Cornish, 2006). The United Nations Gender Empowerment

5 In 2011, nearly 50\% of the World Bank's lending related to gender issues. http://go.worldbank.org/ YHU5EJL1Io, retrieved May 15, 2012.

6 http://www.unwomen.org/ retrieved May 15, 2012.

7 See also http://go.worldbank.org/V45HD4P10o, retrieved February 26, 2012. 
Measure, the Global Gender Inequality Index and Global Gender Gap Index ${ }^{8}$ have also been criticized as being irrelevant to many contexts (Beteta, 2006; VeneKlasen \& Schelen, 2002; Hancock et al. 2011). In lieu of the impossibility of measuring empowerment, Yaron (2008, p. 8) observed that: "We cannot measure empowerment in a way that does justice to its inherent complexity and ... satisfactorily ... What we can do, however, is to identify measurements that capture, albeit imperfectly, important dimensions of changes in power, and that can be complemented by more interpretive and explanatory forms of qualitative research."

The last and the most critical theoretical problem with 'empowerment' relates to the concept on which it is predicated, 'power'. A great deal of literature has tended to conceptualize 'empowerment' as a tool for correcting unequal power relations or a way of increasing the power of the disadvantaged (World Bank, 2000a; Mosse 2001; Narayan, 2002; Cornish, 2006; Tesoriero, 2010). Reference to 'unequal power' assumes that someone is disempowered or disadvantaged in relation to another (Nelson \& Wright, 1995, Mosse, 2001; Mosedale, 2003; Batliwala, 2007). While scholars generally agree that power is a complex and multi-layered concept, they disagree on its form, definition and dimensions.

Attempts to define the concept of power since the late 1980s include the works of Clegg (1989), who categorizes the different interactions of power relations; and Rowlands (1997), who examines the four main forms of power as: 1) Power over; 2) Power to; 3) Power with; and 4) Power from within. Power has also been examined by others, including VeneKlasen and Miller (2002), who explored different aspects of political power; Csaszar's (2004) 'conflictual' or consensual approaches to power; and Vails' (2004) discussion of 'A Theory of Power'. Even so, Tesoriero's (2010) discussion of power is more appropriate for the purpose of this paper because of its currency, conciseness, and that fact that he draws on earlier theorists, such as Wright Mills, Robert Dahl, Talcott Parsons; and Michel Foucault.

According to Tesoriero (2010) the nature of power in modern societies is categorized into Pluralistic, Elite, Structural and Post-structural perspectives. The Pluralistic Perspective considers power as a type of game which the individuals and groups in a given locality or society play competitively. It glosses over the disadvantages an individual or group may have by virtue of their class, gender, race, ethnicity, age, disability, sexuality and geographical location, postulating that all people have equal opportunity to participate, as there is none all-powerful. To win or gain power, one must be equipped or empowered with the capacity or assertiveness to compete effectively, apart from understanding the rules of the game. The Elitist Perspective, Tesoriero argues, does not regard power as a game where all the players have equal opportunities to win. Rather, it views society as hierarchical with a certain few groups having more power than they should. Termed 'elites', they wield the influence to control key institutions and decide on issues that affect the majority. To gain power in an elitist domain, one has to become an elite.

8 These are three gendered indicators for measuring women's empowerment (see UNDP 2007; World Economic Forum 2008; 2010). 
The Structural Perspective of power, Tesoriero (2010) argues, relates to structural or systemic inequality or even oppression as a form of power. By emphasizing the importance of class, race and gender, structural power holders, mainly the elites, reinforce inequalities by putting barriers in place that will keep the disadvantaged perpetually disempowered. Finally, the Post-structural Perspective of power relates to the way language and discourse is used as mechanisms of control (Rabinow, 1984). Drawing on the works of Michel Foucault, Tesoriero argues that power is not just about action, as the earlier perspectives seem to portray; but rather other forms of power which may relate to the way certain discourses are used by the 'powerful' as the norm that should guide and shape communication, for example.

The fact that 'empowerment' is predicated on power gives the term a competitive slant. According to Michel Foucault (1980; 1982) power is not neutral or a 'zero sum' concept and that it is required to overcome other forms of power, be they negative or positive (Csaszar, 2004; Cornish, 2006). In lieu of its competitive tendencies, it can be argued therefore that power cannot be 'shared' between the 'powerful' and the 'powerless'. By implication, 'empowerment' actually means disempowering the one wielding power. Depending on the context, 'empowerment' may dis-empower others by breaking cultural norms, practices and /or certain monopolies and exclusivities enjoyed by a few, usually the elite.

The discussion so far has established that, while inherently 'good', empowerment is a complex term, and would require cautious application in program designs. Theoretically, the notion of the simultaneity of 'empowerment' and 'disempowerment' - the quest to empowering one group could actually lead to the disempowerment of others - also emerged from the discussion. Against this background, the section below examines how the term was applied in Ghana's CBRDP; this would provide insights into the extent to which the poor programming of the projects impacted on its outcomes.

\section{Ghana's Community-Based Rural Development Projects and Empowerment}

As pointed out above, Ghana's CBRRP aimed to empower the hitherto weak local government substructures (Area Councils, Assembly Members and Unit Committees) to plan and implement local projects. The selected Area Councils (local government officials) ${ }^{9}$ were taken through the rudiments of the CBRDP. In seminars conducted by consultants, local government officials were trained in financial, project tendering and procurement management processes. They were also trained in how to prepare project proposals

9 The selection of the Areas Council was based on two criteria: a functioning office with staff and a three-party- signatory bank account. But a number of the Area Councils researched did not have offices. Before the CBRDP, although the Area Councils existed, with no project to implement, they were virtually in a state of inertia, as the District Assemblies executed most local projects. The CBRDP was the seminal nationwide project that tested the facilitation and implementation capacities of the Area Councils 
(Action Plan). The Action Plans contained demographic information and the prioritized needs of the Area Council as well as a project implementation plan and a budget. While they were prepared as a requirement for receiving the CBRDP, the Action Plans were also meant to be the Area Council's development blueprint (CBRDP Implementation Manual, 2006). Once the training was over, the Area Councilors returned to their respective localities to prepare their Action Plans. The process was 'supposed' to be participatory and consultative between the local people [including women], the Assembly and Unit Committee Members, and local people. The Action Plans had to 1) Reflect the most critical 'needs' of the localities; 2) Be explicit about the project's implementation and procurement plans; and 3) Be able to fund a project not more than GHC 15,000. ${ }^{10}$ Once an Action Plan was finalized, it was forwarded to the Zonal Head of the CBRDP to be considered for funding.

There were two types of the funding: the Normal and Rapid Response Initiative (RRI). Under the Normal funding arrangements, the Area Councils received the funding as they progressed and were not time bound. In the RRI category, Area Councils were required to complete their chosen project within a hundred-day limit, after which they received the funds. Once the CBRDP secretariat approved the Action Plan, the beneficiary locality received the seed money in three equal installments into the Area Council's bank account. According to the CBRDP Implementation Manual (2006), District Assemblies had to contribute $10 \%$ of the project sum, while the 'empowered' local government officials were expected to rally their respective localities to contribute labour or offer hired services at a reduced rate. While the CBRDP aimed to empower local government officials, because the latter lacked the technical capacity to implement the projects themselves, they had to collaborate with the municipal/District Assemblies for assistance. Depending on the type of project chosen District Planning Officers, Accountants, and Engineers offered the Area Councils relevant technical support at various stages of project implementation.

While the idea of empowering local government officials was in principle 'good' and pivotal in the design and implementation of the CBRDP, the project's application of 'empowerment' had two major flaws. First, a review of most of the CBRDP documents revealed that 'empowerment' was not theoretically conceptualized, as the researcher did not find a working definition of the term and its theoretical complexities in the training manuals. Being a complex term, the expectation was that the consultants who trained the local government officials would brief them on the theoretical intricacies of the term. But this seemed not to have happened. As a result, over $90 \%$ of the local government officials interviewed tended to understand 'their empowerment' more in terms of: 1) Having an oversight responsibility to manage the project as well as rendering proper fiscal accounts to the CBRDP Headquarters in Accra, the nation's capital; and 2) Encouraging the local people (especially women) to participate in the implementation and maintenance of the projects.

Second, owing to the mal-application of the concept of empowerment in the project, the project's managers failed to anticipate unintended outcomes, particularly; the

10 Approximately US $\$ 10,274$, based on exchange rate effective March $31,2004, \mathrm{GH} \$ 9050=\mathrm{US} \$ 1.25$. 
phenomenon of the simultaneity of empowerment and disempowerment. As argued earlier, the local government officials seemed to have conceptualized their empowerment more in terms of rallying local support for implementing, monitoring and maintaining the projects. Some Traditional Chiefs felt sidelined and disempowered by the CBRDP implementation processes. As the empirical data from the two case studies will show below, this led to conflicts between the Chiefs and local government officials, which eroded any existing social capital in the localities. Ultimately, the conflicts impacted negatively on the maintenance of the projects.

\section{Case Study 1: Aboloo, Simpe Municipality, Greater Accra Region}

Aboloo is a semi-urban town in the Daakye Area Council of the Simpe Municipality of the Greater Accra Region. The Municipality is less than an hour's drive from the nation's capital (see Figure 1). The population of Aboloo was estimated in 2010 to be 2500 (See Simpe Medium Term Development Plan 2010). The town is inhabited by a variety of ethnic groups: GAs form 55\%, Ewes $25 \%$ and other groups, including the Akan and people from the northern part of the country, account for the remaining 20\% (Simpe MTDP, 2010). The main occupation of the residents is agriculture, specifically peasant crop and animal farming, while others are engaged in petty trading. Aboloo had no health centre or clinic; thus, residents relied on health facilities in nearby towns such as Dobro and Daakye. While Aboloo had electricity, significant sections of the town used kerosene for lighting. The town also had four standpipes and three bore holes (Simpe MTDP 2010; Daakye Area Council Action Plan 2006-2009; Field notes, 2011).

The fieldwork revealed Aboloo to have four basic schools: three privately-owned and one government-owned, the Anglican Basic School. This was the basis for constructing a Community Library under the CBRDP in order to uplift the low academic performance of the locality. This problem, as stated in the Daakye Area Council Action Plan (2006-2009), was due to the absence of a library facility in the locality and the generally poor state of the educational infrastructure at the government-owned school, which was a disincentive to teachers posted to the town. The absence of a library facility in Aboloo, as explained further in the Action Plan, had led to high the rate of school dropouts, as parents could not cope with spending lots of money on extra tuition. The construction of a Community Library was therefore regarded as a measure intended to motivate local school children to study, while attracting teachers to the town (See Daakye Area Council Action Plan 2006-2009). In the words of the Team Leader of the project, "We were worried that many pupils could not read in the town. In fact in the lower primary of the Anglican Basic School only thirty-four [out of 130] could read. So we made it our target to raise that number to eighty-four by September 2007 [through the library project]."

The Senior Linguist (spokesman of the Traditional Chiefs) of Aboloo also explained that the library was built to "help the school children with their reading and writing ... [and] also prevent the pupils from going to video game centers at the nights and involving themselves in vices." Because of the urgency to improve the academic performance in the 
locality, the Assembly Member of Aboloo explained that the project was implemented as a Rapid Response Initiative ${ }^{11}$ and strategically situated on the compound of the Anglican Basic School. ${ }^{12}$

Despite the good intentions that informed the construction of the library, the researcher found it in a state of dereliction. Aboloo has 'powerful' Traditional Chiefs who constantly make news for various advocacy issues in the interest of the locality ${ }^{13}$ . Because of their influence, they tended to regard themselves as those to control all development projects in the town, including the CBRDP Library Project. For example, the Senior Linguist of Aboloo when interviewed kept emphasizing his assertion that, "Aboloo is a GA traditional town, so we [Traditional Chiefs and Elders] wield the power to control and manage all development projects in the locality." He went further in arguing that Aboloo benefitted from the CBRDP because of the influence of the Traditional Chiefs in the Municipal Assembly, a claim the local government officials refuted.

Mandated to manage the CBRDPs, the LGOs of Aboloo were not prepared to be dictated to by the Traditional Chiefs. These officials, some of who did not hail from the town, argued that the CBRDP was explicit about empowering local government officials to manage the project. While admitting that Traditional Chiefs were important stakeholders in the CBRDP implementation processes, the LGOs indicated that their role was only ceremonial. A 48-year-old man, who was a Unit Committee Member of Aboloo, captured this attitude succinctly when he argued that:

At the training session, the CBRDP officials from Accra told us that we must manage the project and render all accounts. So, we have a duty to the CBRDP Headquarters and the people who elected us and not to Traditional Chiefs ... the [CBRDP] officials explained that if anything went wrong with the project, they would hold us responsible and Aboloo may not get such a project again.

After the project was completed and commissioned on November 08, 2007, the Senior Linguist explained that the Traditional Chiefs and Elders of Aboloo demanded that the LGOs hand over all documents and render accounts on the project to them. However the 'empowered' Unit Committee Members refused to heed the Chiefs' requests on the grounds that the CBRDP officials in Accra had not authorized the directive. Apparently annoyed by the actions of the LGOs, the Traditional Chiefs of Aboloo announced, in a dawn broadcast, that the Unit Committees Members had been suspended indefinitely from operating in the locality. The announcement went further to indicate, "The Unit Committees Members would have themselves to blame if they flouted the order". Confirming the suspension, the Senior Linguist of Aboloo explained that they took

11 Constructed in a hundred days.

12 Private schools and individuals could access the library.

13 See for example, http://sethbnewsog.blogspot.com.au/2010/o2/arrest-this-man-page-3.html, retrieved June 28, 2012.

52 GJDS, Vol. 9, No. 2, October, 2012 
the action because, as he put it, "the local government officials were challenging our authority".

Threatened by the broadcast, a Unit Committee Member indicated that they had to "wash their hands of" the library for fear of their lives. The LGOs criticized the Chiefs' action as unconstitutional and, in consultation with the Municipal Assembly, filed a lawsuit against the Traditional Chief and Elders of Aboloo at the Accra High Court. Although the Assembly Member would not comment on the issue, he hinted that the attitudes of the Elders were impacting on his work and the organizing of assets in the locality. Indicating his resolve not to contest the 2010 local government elections because of the conflict, the Assembly Member explained that the state of the library was an embarrassment to the locality.

Unit Committees are the bridge between the local people and the Area Councils. Working with the Assembly Member, they relate to people at the grassroots level; they listen to their concerns for onward discussions during the Area Council meetings. Unit Committees are very instrumental in local mobilization and project maintenance (Article 240 [48], Constitution of the Republic of Ghana 1992). Owing to their suspension, between November 2007 and March 2011, when the fieldwork was completed, Aboloo did not have a functioning Unit Committee that would have otherwise mobilized the local people to maintain the library. While the Senior Linguist indicated that the Traditional Chiefs were sourcing resources for maintaining the library the researcher did not witness the project improve in any way during the field work.

Of the all the projects studied in Zone IV, the researcher found the Aboloo Library to be the most neglected. Several cracks were visible in the structure and staircase. Many of the windows either had no louvers or were broken. The library had no electricity connected and there were no fans. In the afternoons the place could be so hot that one female JHS 1 pupil remarked, "It's difficult to concentrate in the heat. It is terrible to study without fans. Some of my friends even use the books to fan themselves". A majority of pupils in the JHS 2 and above also explained that most of the books in the library were irrelevant to their studies or were outdated. Furthermore, there were not enough books for some sections and subjects, while others had none. For example, the French, ICT and Ghanaian languages sections had no books, while the mathematics section had only five; the library also had no computer. The Librarian explained:

We haven't got any books since the library was commissioned. Those here were made possible by the out-gone District Education Director. Sometimes, good people also walk in and give us books ... because of the book deficits [when they are torn] I mend the pieces and put them back on the shelves, even if some pages are missing.

Because of the conflict, many crucial administrative and resource challenges impacted on the efficiency of the library. The first related to the library's operating hours. The library opened and closed during the Anglican Basic School's operating hours (8:00 am-3:30pm). It was not opened at nights, during weekends or on holidays. Pupils in the private schools 
also found the opening and closing times of the library discriminatory. A male JHS 2 student of one of the private schools said, "we are not experiencing the benefits of the library because they close at the government school times, whilst we finish later. They don't also open it on Saturdays and Sundays." When asked why the library closes early, does not open in the nights, on weekend and holidays, the Head Teacher of the Anglican Basic School explained:

Hmm [deep sigh] I have discussed it with the librarian. But I have discovered that he needs an incentive to do those extra hours. But the motivation is not forthcoming.... Another issue is that unlike librarians employed by the Ghana Library Board who work on weekends, in the evenings and on holidays, our librarian is a teacher employed by the Ghana Education Service and expected to work within our 8:0oam $-3: 30$ pm opening and closing times. The community support has to support and pay him some extra money, if they want the library opened outside the school hours...otherwise it will not be serving the purpose for which it was built".

Although the library was meant for all pupils in the locality, it could not accommodate a standard class of forty pupils, as the quantity of furniture was inadequate. Whenever the library was full, the other pupils had the options of either sitting on the floor or standing to read. If the class was large, those who could not access the library had to sit in the classroom, having missed the allocated "library hour" on the timetable. A teacher from one of the private schools explained that they scarcely visited the library as it was always full and there were not enough relevant textbooks. He was also of the opinion that each school in the locality should be allocated days and times to use the facility. In separate interviews, the Librarian, Head Teacher and the Senior Linguist appealed for support for the library. The Project's Team Leader expressed similar concerns when he said: "I visited the library last week and I saw how the project has been left unmaintained. The staircase has cracks all over and some of the louvers are off. On top, there are not enough books ... this is becoming disgraceful."

The above analysis points to what could become of 'good' project such as Aboloo's Library Project, that are based on complex concepts, but whose outcomes are not monitored and managed. While the CBRDP aimed to 'empower' Aboloo's local government officials, it seemed not to have envisaged the consequences of sidelining the locality's influential Traditional Chiefs; in fact the final outcome was disempowering for many. Aboloo is just one of the many localities in Ghana where fracas between Traditional Chiefs and local government officials negatively impact on development projects. Ntoaso, a town in the Abusua Municipality of the Eastern Region, is another case in point. 


\section{Case Study 2: Ntoaso, Abusua Municipality, Eastern Region}

Ntoaso received a sixteen-seater public toilet facility from the CBRDP. Located almost seventy-five kilometres from Accra, Ghana's capital city, Ntoaso falls under the Abusua Municipality of the Eastern Region of Ghana. The town is inhabited by Akyem, the traditional land owners, Ewe, Akwapim and people from the northern parts of the country. Many of the residents engage in palm oil business, farming and petty trading. Because the locality is not far from major trading spots such as Adesso, Fiapre and Accra, many of the traders and farmers commute to these centers to sell their wares and return the same day. Ntoaso has electricity, pipe born water and one government-owned basic school (Abusua Municipal MTDP 2010).

Before the implementation of the CBRDP's sixteen-seater facility in 2008, Ntoaso had only one public toilet facility, which was donated by the European Union. As of 2009, this facility located north of the town was insufficient to serve the town's population of almost nearly four thousand, (Ntoaso Area Council Action Plan, 2006-2009). Those on the south opined it was too far from them, apart from the fact that they had to sometime join long queues to use it. In fact, up to the period of the fieldwork, the EU toilet facility was not in use as it had cracks and posed dangers for users. The lack of public toilet in the town, the Ntoaso Area Council Action Plan (2006) stated, had led to indiscriminate defecation in the town, a situation that led to the outbreak of cholera in the town. Thus, when the town was chosen as a beneficiary of the CBRDP, it was greeted with joy as many deemed it timely. The project was completed and in use as the fieldwork finished.

However, during most visits to the facility, the researcher observed that it was not being well-maintained. For example, although tokens were being charged for using it, the facility appeared to be untidy. This annoyed many of the users, some of who refused to pay the token on the grounds that the monies were not being used for its maintenance. Frustrated by the situation, the caretaker explained that she could not enforce the payment of the user fees as the facility looked unkempt. As this case study will show, the project was in this state because the Traditional Chief of the Town was quarrelling with the Area Council Chairman and Assembly Member of the town over who had the 'power' to manage the facility.

An indigene of Fiapre, the Traditional Chief had ruled Ntoaso for twenty-one years. As most Traditional Chiefs in Ghana would claim, the Ntoaso Chief indicated that his ancestors owned the land of Ntoaso and therefore had a default right to oversee all development projects in the locality, including the CBRDP public toilet facility. Since October 2008, when it was completed, the Chief had complained about what he termed as the "arrogance of the Assembly Member" of the locality. He argued that: The Assembly Member and his so-called [Unit] Committee Members, who manage the project, are over stepping their borders. Before he became the Assembly Member I was the Chief. Yet, he is 
still holding unto the keys of the toilet and has refused to hand them over to me and my Elders.

The Chief considered the Assembly Member's refusal to hand over the keys as a challenge to his traditional authority and indicated that he was in a process of auditing the facility's user fee proceeds. Further probes during the interviews with him revealed his poor understanding of the fact that the CBRDP was designed to be managed by local government officials. For example, when the researcher asked him what he knew about the project, he claimed that the CBRDP was sponsored from the coffers of the District Assembly; and that it was a way of thanking the residents for being stalwart followers of the New Patriotic Party, under whose government (2001-2008) the project was implemented. Apparently ignorant about the terms of the CBRDP, the Chief was drawing on his traditional 'powers' to demand the right to control the project.

The Assembly Member in question had been in office for eight years (2003-2010) and also served as the Area Council Chairman for four years (2006-2010). He recounted the frustrations he encountered in getting the Municipal authorities to approve Ntoaso as a beneficiary of CBRDP funds. Interestingly, the Chief also claimed that it was his goodwill with the Municipal Chief Executive (MCE) that led to the choice of Ntoaso as the location of the new toilet facility. The Assembly Member denied this, explaining that the CBRDP was not for Traditional Chiefs, but about the strengthening of local government institutions. As a result, he and the Unit Committees owed a duty to the Government of Ghana to manage the project and not to the Traditional Chief, although he was ready to render accounts to the latter, if asked.

During a visit to the town, the Traditional Chief and Elders had summoned the Assembly Member to render accounts on the project. The Chief reported:

Last week the Assembly Member came and rendered the accounts on the project. But we [the Chief and his Elders] were dissatisfied and doubted the figures ...We feel there is something fishy somewhere because although the Assembly Member claimed that he sponsored part of the project with his personal money and that the community owes him a total sum of about $\mathrm{GHC} 5 \mathrm{500}^{14}$, we are aware that that the District Assembly fully funded it, while the community contributed labour.

According to the Assembly Member, when the project was approved by the CBRDP secretariat, it was supposed to be a sixteen-seat toilet facility. When the work started, it was not known that the MCE had ordered the project sum be equally divided between Ntoaso and Bupie, a town in the Municipality also in need of a toilet facility. This brought the Ntoaso project to a standstill for a while as the local government officials were finding it difficult to change the project to an eight-seater facility. However, the Assembly Member decided to go ahead with the original sixteen-seater plan and hoped that the local people

14 At the time GHC $1=$ USD 0.5 . 
would help with tokens. Unfortunately, while some residents contributed, many did not. Under the circumstances, he had to use his own monies to complete the project, hoping that he would be reimbursed later from the facility's user fee proceeds.

The Assembly Member explained further that the Unit Committee Members and the Zone IV Headquarters of the CBRDP were aware of the monies owed him. Further, he explained that although he had produced receipts to support his claims, the Traditional Chief and his Elders suspected that he had concocted the figures. He asserted that until he recouped all the debt owed him, he was not ready to hand over the project to the Chief.

Concerning the maintenance of the toilet facility, the Assembly Member indicated this to be the responsibility of all the residents, the user fees not being enough for the upkeep of the facility. In addition, because the facility was constructed as a communitybased project, the he expected that the Chiefs would support him to organize communal labour for its maintenance. However, owing to the lack of cooperation from the Traditional Chief and his Elders, he explained that he was reluctant to call for communal labour to clean the toilets or clear the bushes around it. Such an initiative could be interpreted to mean as him undermining of the authority of the Traditional Chief ${ }^{15}$ . Some women the researcher interviewed indicated that as the facility was surrounded by bushes they were concerned about being bitten by snakes if they made use of it in the early morning or at night times.

While other informal interviews indicated that the Assembly Member had the support of most residents in the locality, he admitted to fearing for his life. Consequently, although he was eligible to contest the 2010 local government elections, he voluntarily stepped down, blaming the decision on his dispute with the Traditional Chief and his Elders. He said:

I have had enough of the Chiefs, who know nothing about local governance. I'm out and out for good. I'm only biding the time to recoup my money and then hand over the keys to the CBRDP officials, who put me in charge of the project. If they give the project to the Traditional Chiefs to manage it, I care less.

Meanwhile, as of July 2012, key informants from Ntoaso contacted by the researcher indicated the toilet facility to be in no better state than it was in March 2011 when the fieldwork was concluded. Furthermore, while the former Assembly Member had handed over the keys, the CBRDP authorized the new local government officials to manage it. Consequently, as of July 2012 the Traditional Chief and his Elders have not been cooperating with the new officers to organize communal labour to maintain the toilet facility.

15 In many traditional areas in Ghana, Traditional Chiefs call for communal labour. 


\section{Conclusion}

This paper has shown the manner in which the mal-application of 'empowerment' in the CBRDP led to tensions between local government officials and Traditional Chiefs, which ultimately impacted on the project's outcomes. The paper also revealed the theoretical complication around the term 'empowerment' and highlighted the need to be cautious in applying it in development program designs. Aside from the tendency to be genderspecific and despite being a generic term, measuring empowerment presents many challenges, as scholars disagree on whether the term is a process or an outcome or both. The fact that 'empowerment' is predicated on the concept of 'power' makes it even more complicated. The reason for this dilemma is that 'power' is not a neutral concept and cannot be shared; empowering one group may mean disempowering others by breaking certain traditional norms or monopolies. This may lead to conflicts, if outcomes are not properly monitored as shown in this paper. Despite these theoretical challenges 'empowerment' appears to have been loosely applied in the CBRDP as the project:1) Had no working definition of 'empowerment'; 2) Designers failed to anticipate unintended outcomes, particularly; the phenomenon of the simultaneity of empowerment and disempowerment.

Analysis of the empirical data collected during fieldwork and drawn from Ntoaso in the Eastern Region and Aboloo in the Greater Accra Region showed that in their pursuit to strengthen Ghana's decentralization process through the CBRDP, the project's designers focused on the local government sub-structures, while overlooking the country's influential Traditional Chieftaincy establishment. While the intent to empower Assembly and Unit Committee Members was important, the project's designers ignored the reality that the local government officials did not function in isolation, but were part of a very complex socio-cultural system, a system that draws heavily on the influence of Traditional Chiefs to provide the cohesion, support and social capital required in development programs. Owing to the conflict that the notion of power tends to generate, the project could have been more effective if Traditional Chiefs were briefed about its intent or involved in the implementation processes. Because this did not happen, the Chiefs tended to view the $\mathrm{CBRDP}$ as a threat to their authority.

In sum, efforts at making development effective should pay closer attention to the use of normative, yet complex concepts in program designs. Such attention should begin with investing in social research activities that employ credible methodologies for understanding the social and politico-cultural realities of development beneficiaries. This is crucial if projects meant to improve the lives of people in developing countries are to be sustainable. As this paper has shown, understanding such grounded realities of 'development' beneficiaries is more important than designing projects based on romanticized terms espoused by international development agencies. 


\section{References}

Abotchie, C. (2006). "Has the position of the chief become anachronistic in contemporary Ghanaian politics?" In: I.K. Odotei \& A.K. Awedoba (Eds.). Chieftaincy in Ghana culture, governance and development (169-181). Accra: Institute of African Studies.

Adusei-Asante, K. (2013). “Towards Aid Effectiveness: Contested Theories and Concepts: A Case Study of Ghana's Community-Based Rural Development Project.” A PhD Dissertation, Edith Cowan University, Australia (unpublished).

\& Hancock, P. (2012). “Theories in Community-Driven Development Operations: A Case Study of Ghana's Local Government System.” European Journal of Business and Social Sciences, 1(5), pp. 83-98.

Ahwoi, K. (2005). Recentralisation within decentralization; A review of the Local Government Act, 2003, Act 656 (June. ISSN 0885-2460). Accra, Institute of Economic Affairs (IEA).

(2010). Local Government and Decentralization in Ghana. Accra, Ghana: Unimax Macmillan.

Alsop, R. Bertelsen, M. \& Holland, J. (2006). Empowerment in practice: from analysis to implementation. Washington, DC: World Bank.

Antwi-Boasiako, K.B. (2010). "Public administration: local government and decentralization in Ghana." Journal of African Studies and Development, 2(7), 166175 .

Anyidoho N.A. \& Manuh, T. (2010). "Discourse on Women Empowerment in Ghana." Development, 53(2), pp. 267-273.

Apusigah, A. A. (2004a). "Empowering women for community development: revisiting the two imperatives of the practical and the strategic." Ghana Journal of Development Studies, (1), pp. 4-24.

(2004b), Gender Mainstreaming the Ghana Poverty Reduction Strategy or is it? http://www.isiswomen.org/wia/wia2-o4/agnes.htm, Retrieved June 15, 2011.

Arcand, J. \& Bassole, L. (2007). “Does community driven development work? Evidence from Senegal." Working Paper, CERDI.

Arhin, K. (2002). The Political Systems of Ghana: Background to transformations in traditional authority in the colonial and post-colonial periods. Historical Society of Ghana: Accra, Ghana. 
Arnstein, S.R. (1971). "Eight rungs on the ladder of participation." In Cahn, C.S. \& Passett B.A (Eds), Citizen Participation: Effecting community change (69-91). New York: Praeger Publishers.

Batliwala, S. (2007). "Putting the Power Back into Empowerment." Available online at http://www.opendemocracy.net/article/putting power back into empowerment_o. Retrieved 16/05/12.

Betata, H.C. (2006). "What is missing in measures of women's empowerment?" Journal of human development7 (2), pp. 221-241.

Binswanger-M. H.P., de Regt, J.P., Spector, S. (2010). Local and Community-Driven Development. Washington, DC: The World Bank.

Botchway, K. (2001). "Paradox of Empowerment: Reflections on a Case Study from Northern Ghana." World Development 29 (1), pp. 135-153.

Burnside, C. \& Dollar, D. (2000). “Aid, policies and growth.” American Economic Review, 90(4), 847-868.

Chambers, Robert (1983). Rural Development: Putting the Last First. London: Longman.

Cleaver, F. (2001). "Institutions, agency and the limitation of participatory approaches to development.” In: B. Cooke \& U. Kothari (Eds.). Participation: the new tyranny (3655). London and New York: Zed Books.

Clegg, S. (1989). Frameworks of Power. Sage, London

Community-Based Rural Development Project (2006). Implementation Manual. Accra, Ghana.

Community-Based Rural Development Project (2005, 2006, 2007, 2008). Annual National and Zonal Reports. Accra, Ghana.

Cooke, B. \& Kothari, U. (2001). Participation: The New Tyranny? Zed Books: London.

Cornish, F. (2006). "Empowerment to Participate: A Case Study of Participation by Indian Sex Workers in HIV Prevention.” Journal of Community \& Applied Social Psychology (16), pp. 301-315.

Cornwall A. \& J. Edwards (2010). "Introduction: Negotiating Empowerment," IDS Bulletin, 41(2), 1-9.

Csaszar, F (2004). Understanding the concept of power. In: R. Alsop (2004). Power, rights, and poverty: concepts and connections (137-146). [A working meeting]. DFID \& The World Bank. 
Donkoh, W. J. (2005). "Traditional leadership, human rights and development: the Asante example." Department of General and African Studies, KNUST, Kumasi.

Dreier, J. (1993). “Structures of Normative Theories.” The Monist (76), pp. 22-40

Foucault M. (1980). Power/Knowledge: Selected Interviews and Other Writings 19721977). Ed. C. Gordon. Brighton, UK: Harvester Press.

(1982). “Subject and Power." Critical Enquiry 8 (4), pp. 777-795.

Giddens, A. (1984). The Constitution of Society: Outline of the Theory of Structuration. Cambridge: Polity Press.

Hancock, P., S., Middleton, J., Moore \& I. Edirisinghe (2011). Gender, Status and Empowerment: A study among women who work in Sri Lanka's Export Processing Zones (EPZs). ECU, Australia.

Lavarack, G. \& Wallenstein, N. (2001). "Measuring Empowerment: A fresh look at organizational domains." Health promotion International 16(2), pp. 179-85.

Maseno L. \& and Kilonzo S.M. (2011). "Engendering development: Demystifying patriarchy and its effects on women in rural Kenya." International Journal of Sociology and Anthropology Vol. 3(2) pp. 45-55.

Mansuri, G. \&. V. Rao (2004). "Community-Based and -Driven Development: A Critical Review." The World Bank Research Observer 19 (1), pp. 1-39.

Mosedale, S. (2003). "Towards A Framework For Assessing Empowerment." (Working Paper Series. Paper No: 3). Institute for Development Policy and Management, University of Manchester, Harold Hankins House, Precinct Centre, Oxford Road, Manchester.

Mosse, D. (2001). "People's knowledge, participation and patronage: operations and representations in rural development." In: B. Cooke \& U. Kothari (Eds.). Participation: the new tyranny (16-35). London and New York: Zed Books.

Narayan, D. (1995). The Contribution of People's Participation: Evidence from 121 Rural Water Supply Projects. ESD Occasional Paper Series 1. World Bank. (2002). (ed). Empowerment and Poverty Reduction: A Sourcebook. World Bank, Washington D.C. 2002.

Nelson, N \& Wight, S. (1995). Power and Participatory Development: Theory and Practice. Intermediate Technology Publications, London

Nozick, R. (1974). Anarchy, State, and Utopia. New York: Basic Books. 
Nussbaum, M. (2000). Women and Human Development: The Capabilities Approach. Cambridge: Cambridge University Press.

Putnam, R. D. (2002). "Democracies in flux." In Putnam, R.D. (ed.). The evolution of social capital in contemporary society. Oxford: Oxford University Press.

Rowlands, J. (1997). Questioning Empowerment: Working with Women in Honduras. Oxford, UK: Oxfam Publications.

Scheffler, S. (1982). The Rejection of Consequentialism. Oxford: Oxford University Press.

Tesoriero, F. (2010). (4 $4^{\text {th }}$ ed). Community Development. Community-Based Alternatives in an Age of Globalization. Australia: Pearson Australia.

Vails, J. (2004). A Theory of Power. Lincoln: iUniverse, Inc.

VeneKlasen, V. L, \& Miller, V. (2002). A New Weave of Power, People, and Politics: The Action Guide for Advocacy and Citizen Participation. Oklahoma City: World Neighbors.

World Bank (2000). World Development Report 2000/2001: Attacking Poverty. New York: Oxford University Press for the World Bank.

(2001). Engendering Development Through Gender Equality in Rights, Resources and Voice. World Bank, Washington DC.

(2002). Empowerment and Poverty Reduction: A Sourcebook. World Bank, Washington DC.

(2003). World Development Report 2004: Making Services Work for Poor People. Washington, DC: World Bank.

Yaron, G. (2008). Measuring Empowerment: A Mixed-Method Diagnostic Tool for Measuring Empowerment in the Context of Decentralization in Ghana. Washington, DC: World Bank.

Zimmermann M.A (1995). Psychological empowerment: issues of illustrations. American Journal of Community Psychology 23, pp. 581-589. 